This item was submitted to Loughborough's Research Repository by the author.

Items in Figshare are protected by copyright, with all rights reserved, unless otherwise indicated.

\title{
Synthesis and solid state structure of pyridyl diboroxines linked by a chiral spacer analogous to Troger's base
}

\section{PLEASE CITE THE PUBLISHED VERSION}

http://dx.doi.org/10.1016/j.tetlet.2014.11.094

\section{PUBLISHER}

(C) Elsevier Ltd

VERSION

AM (Accepted Manuscript)

\section{PUBLISHER STATEMENT}

This work is made available according to the conditions of the Creative Commons Attribution-NonCommercialNoDerivatives 4.0 International (CC BY-NC-ND 4.0) licence. Full details of this licence are available at: https://creativecommons.org/licenses/by-nc-nd/4.0/

\section{LICENCE}

CC BY-NC-ND 4.0

\section{REPOSITORY RECORD}

Elsegood, Mark R.J., and Marc C. Kimber. 2019. "Synthesis and Solid State Structure of Pyridyl Diboroxines Linked by a Chiral Spacer Analogous to Troger's Base”. figshare. https://hdl.handle.net/2134/16853. 


\section{Graphical Abstract.}

Synthesis and solid state structure of pyridyl

Leave this area blank for abstract info.

diboroxines linked by a chiral spacer

analogous to Tröger's base

Mark R. J. Elsegood, Marc C. Kimber*

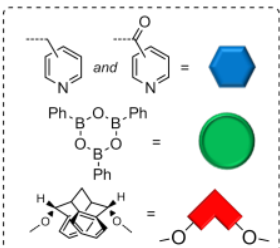

$\mathrm{O}_{\mathrm{O}-\mathrm{O}} \frac{\mathrm{PhB}(\mathrm{OH})_{2}}{6 \text { equiv. }}$

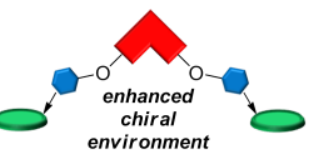




\title{
Synthesis and solid state structure of pyridyl diboroxines linked by a chiral spacer analogous to Tröger's base
}

\author{
Mark R. J. Elsegood, Marc C. Kimber* \\ Department of Chemistry, Loughborough University, Leicestershire, LE11 3TU, UK; Tel: ++44 (0) 01509222570. \\ E-mail:M.C.Kimber@lboro.ac.uk
}

\section{ARTICLE INFO}

\section{ABSTRACT}

\section{Article history:}

Received

Received in revised form

Accepted

Available online

\section{Keywords}

boroxine

boronic acid

pyridyl

chiral cleft

self-assembly
Pyridyl assisted templating of phenyl boronic acid has been utilised to link two remote boroxines via a chiral spacer. The chiral spacer is a carbocyclic analogue of Tröger's base and contains a unique chiral cavity, and the flanking boroxine units have been shown, by single crystal X-ray analysis, to extend the size and shape of this cavity.

2009 Elsevier Ltd. All rights reserved.
The carbocyclic dione cleft molecule $\mathbf{1}^{1}$ has become a valuable surrogate for Tröger's base ${ }^{2 a}$ in catalysis, supramolecular chemistry and chiral recognition (Figure 1). ${ }^{2 \mathrm{~b}} \mathrm{It}$ is analogous to Tröger's base as it contains a $\mathrm{C}_{2}$-symmetric axis and a chiral cavity with a defined geometry and a rigid, predictable structure. The advantages of $\mathbf{1}$ over Tröger's base lie in the dione, which can be conveniently and stereoselectively reduced to give the diol $\mathbf{2}$ (see $\mathbf{2 a}$ and $\mathbf{2 b}$ for alternative views).

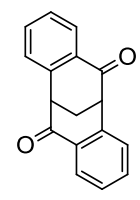

1

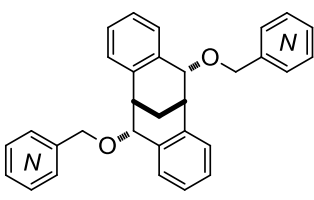

3a: 4-pyridyl

3b: 3-pyridy

3c: 2-pyridyl

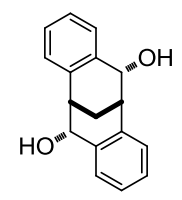

2

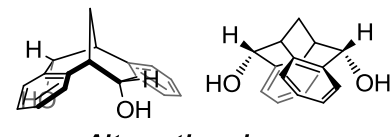

Alternative views

2a

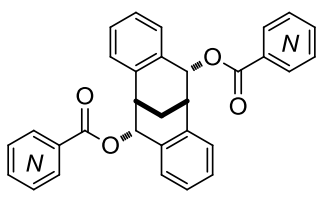

4a: 4-pyridyl

4b: 3-pyridy

4c: 2-pyridyl
Figure 1. The carbocyclic dione cleft molecule 1, its reduced form $\mathbf{2}$ (alternative views $\mathbf{2 a}$ and $\mathbf{2 b}$ ), and the functionalised analogues 3a-c and $\mathbf{4 a - c .}$

This reduction then positions the two hydroxyl groups into the chiral environment of the cleft giving the ability, via hydrogen bonding, to orientate and organise substrates into the chiral cavity (Figure 1). It is this singular attribute of $\mathbf{1}$ which has been successfully exploited in the development of new catalysts and novel supramolecular assemblies. .b,c, $3,4,5$

To date, the only functionalization of these hydroxyl groups has been by esterification and alkylation; ${ }^{1 \mathrm{~b}, 4}$ for example, we successfully demonstrated that the diol could be selectively transformed into the mono- and dipyridyl analogues, with the potential to interact with transition metals. ${ }^{5}$ This type of interaction with transition metals is typical for pyridyl ligands of this kind, as demonstrated by Harding and co-workers who exploited such binding for the self-assembly of [2+2]macrocycles. ${ }^{3 \mathrm{~d}}$ However, we perceived an opportunity to use the pyridyl groups attached to these hydroxyl groups, in the selfassembly of boroxines. ${ }^{6}$ Boroxines are the result of the trimerisation of boronic acids, which is typically achieved by dehydration, however, their formation can be assisted by $N$ coordinating ligands such as pyridine, and as such, this can be thought of as a templating strategy for their formation (Scheme $1)^{7}$

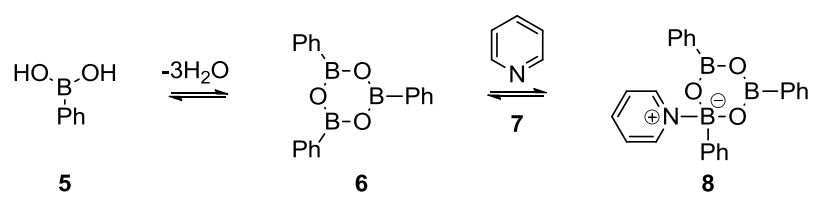

Scheme 1. The self-assembly of boroxine-pyridyl adduct 8 via stabilization of $\mathbf{6}$ with 7. 
In a wider context, boroxines are becoming increasingly prevalent due to their use in self-assembly and particularly in the formation of covalent organic frameworks (COFs), the first of which was reported by Yaghi in $2005 .^{8}$

In this Letter, we disclose our efforts on the self-assembly of ligand sets $\mathbf{3 a - \mathbf { c } ^ { 5 }}$ and $\mathbf{4 a - \mathbf { c } ^ { 5 }}$ with phenyl boronic acid. This would serve two purposes: (1) it would demonstrate the first nonorganometallic self-assembly of a carbocyclic Tröger's base analogue/s; and (2) it would be the first example of linking two remote boroxine units with a chiral spacer unit, which may enhance the binding cavity of our chiral cleft for the purposes of molecular recognition (Scheme 2).
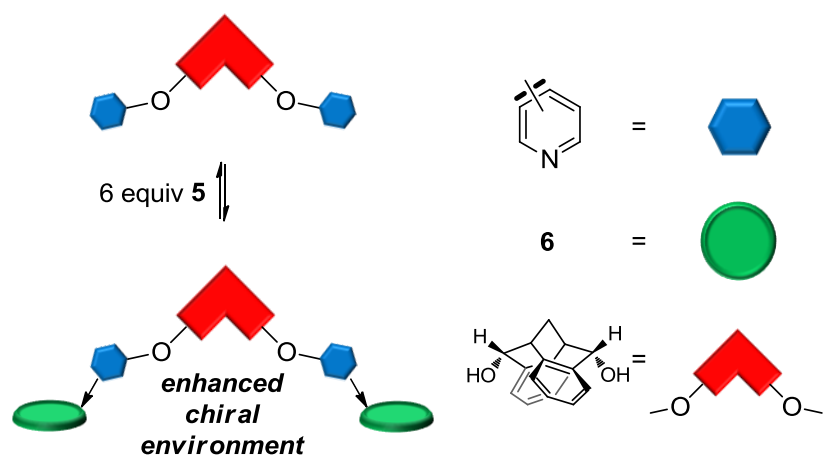

Scheme 2. The linking of two remote boroxines via a chiral spacer.

Initially in this study, we used the racemic clefts 4- (3a), 3- (3b), and 2-dipyridyl ether (3c), which have been previously synthesised and fully characterised. ${ }^{5}$ Consequently, taking 3a (1 equiv) with phenylboronic acid 5 (6 equiv) in $\mathrm{CH}_{2} \mathrm{Cl}_{2}$, we found that the boronic acid rapidly solubilised to give a homogenous reaction mixture (Scheme 3). Upon removal of the solvent the ${ }^{1} \mathrm{H}$ and ${ }^{13} \mathrm{C}$ NMR spectra of the crude white solid showed the formation of one discrete product which was assigned to $\mathbf{3 a . 6}_{2}{ }^{9,10}$ This was based on the downfield shift of the pyridyl signals of $\mathbf{3 a . 6} \mathbf{6}_{2}$ relative to $\mathbf{3 a},{ }^{11}$ and the formation of the adduct was further support by an $m / z$ value of 1081.4452 .
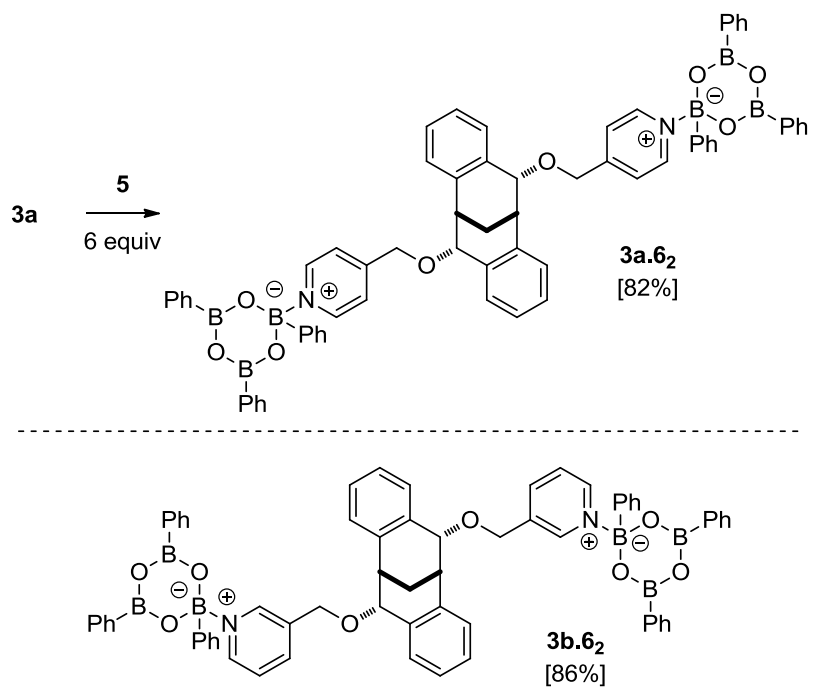

Scheme 3. The formation of bis-boroxine adducts $\mathbf{3 a . 6 _ { 2 }}$ and 3b.6.

Similarly, $\mathbf{3 b}$ was exposed to the same conditions to give $\mathbf{3 b . 6}_{\mathbf{2}}$ as supported by ${ }^{1} \mathrm{H}$ and ${ }^{13} \mathrm{C}$ NMR spectra and an $\mathrm{m} / \mathrm{z}$ value of 1081.4462. However, the 2-pyridyl ligand $\mathbf{3 c}$ in the presence of
5 failed to give the adduct with the ${ }^{1} \mathrm{H}$ NMR spectrum being identical to that of the parent ligand $\mathbf{3 c}$.

With the success of the ether series we next investigated the esters 4a-c. Accordingly, the 4-dipyridyl ether $\mathbf{4 a}$ was exposed to 6 equiv of 5 which yielded the pyridyl adduct $\mathbf{4 a . 6}_{2}$ in quantitative yield (Scheme 4). Once again ${ }^{1} \mathrm{H}$ and ${ }^{13} \mathrm{C} \mathrm{NMR}$ spectra supported the structure. We were also able to deliver 4b.6 $6_{2}$ from $4 b$, and once again the ${ }^{1} \mathrm{H}$ and ${ }^{13} \mathrm{C}$ NMR spectra, together with mass spectral analyses, supported the formation of the assigned structure. However, in line with the 2-pyridyl ligand $\mathbf{3 c}$ above, $\mathbf{4 c}$ failed to assemble. We believe that both $\mathbf{3 c}$ and $\mathbf{4 c}$ failed to give the desired bis-boroxine adducts due to unfavourable steric interactions.
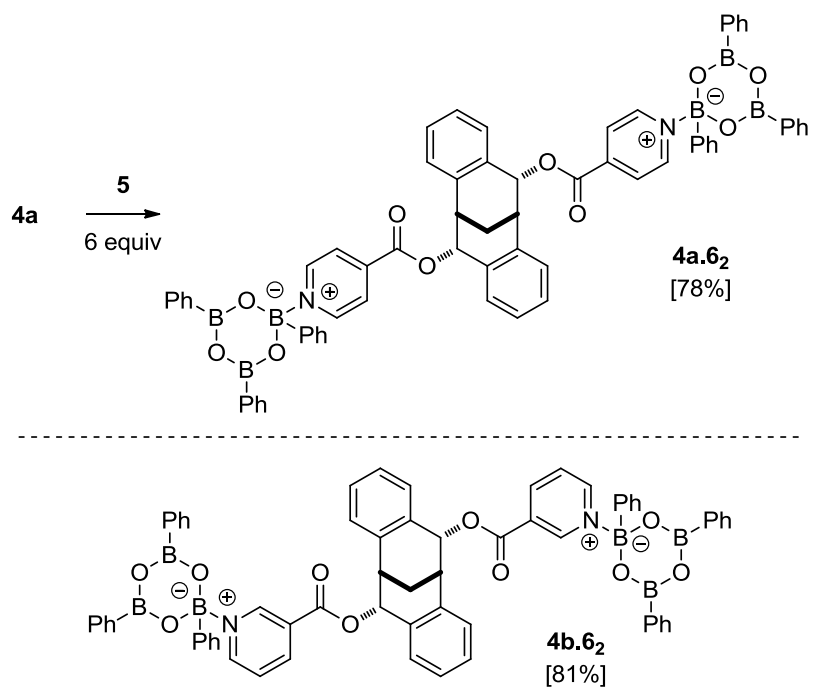

Scheme 4. The formation of bis-boroxine adducts $\mathbf{4 a . 6}$ and 4b.6.

To assign fully the structures of these novel bis-boroxines we deemed it necessary to acquire crystals suitable for single crystal $\mathrm{X}$-ray analysis. Additionally, this would give an insight into the effect, if any, that the boroxine would have on the chiral cavity of the cleft. After exhaustive attempts, adducts $\mathbf{3 b . 6 _ { 2 }}, \mathbf{4 a . 6 _ { 2 }}$ and $\mathbf{4 b . 6 _ { 2 }}$ proved to be uncooperative, but gratifyingly, adduct $\mathbf{4 a . 6}$ delivered crystals suitable for single crystal X-ray analysis, and we were able to assign unambiguously its structure (Figures 2 and 3). ${ }^{12-15}$

The compound $\mathbf{3 a . 6 _ { 2 }}$ crystallises as the racemate with the molecule lying on a two-fold axis; thus half is unique. Associated with each molecule of $\mathbf{3 a . 6 _ { 2 }}$ are three molecules of dichloromethane (Figure 2). One of these forms $\mathrm{C}-\mathrm{H} \cdots \pi$ \{ring centroid $\cdots \mathrm{H}(34 \mathrm{~A})=2.67 \AA$ interactions with the aromatic rings in the cleft. The other two simply fill voids in the crystal lattice. The boroxine rings and the phenyl groups directly attached to them interact via $\pi \cdots \pi$ stacking across inversion centres to those on a neighbouring molecule, with closest contacts in the range 3.46-3.50 A [Figure 3(ii)]. 


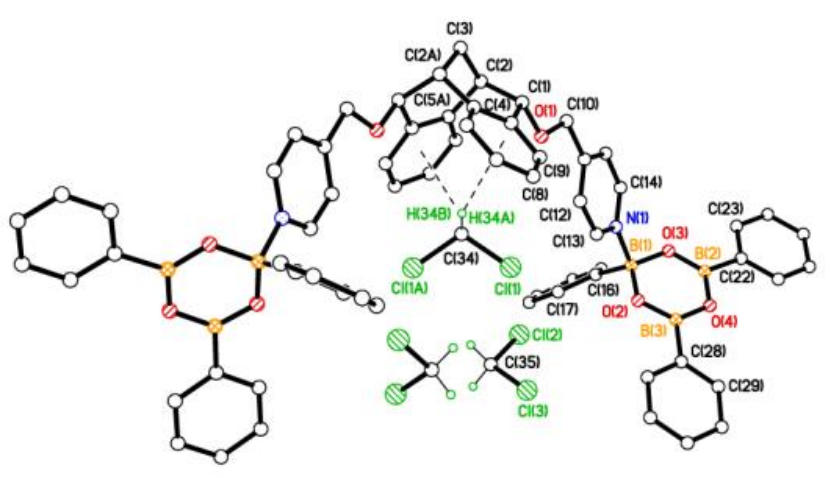

Figure 2. X-ray crystal structure of $\mathbf{3 a} . \mathbf{6}_{2} \cdot \mathbf{3} \mathbf{C H}_{\mathbf{2}} \mathbf{C l}_{2}$.

As can be seen from Figures 2 and 3, the pyridyl-assisted assembly of the bis-boroxine clearly extends the size and shape of the pre-existing cleft contained within $\mathbf{4 a}$ in the solid state. This is demonstrated by the inclusion of solvent molecules within the cavity of $\mathbf{4 a . 6 _ { 2 }}$. Additionally, to our knowledge, this is the first example of a crystal structure of a bis-boroxine adduct.

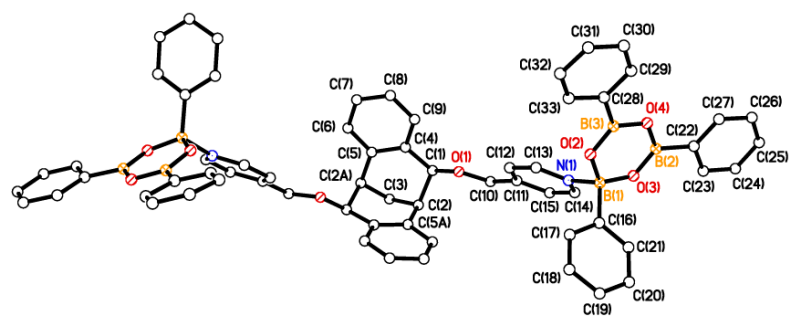

(i)

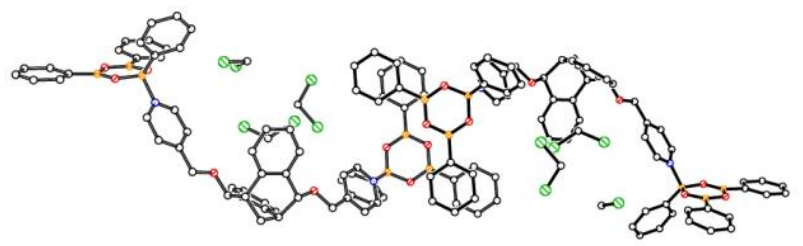

(ii)

Figure 3(i) Alternative view of $\mathbf{3 a . 6} \mathbf{6}_{2}$; (ii) a pair of molecules of 3a.6 $\mathbf{6}_{2}$ highlighting the centrosymmetric $\pi \cdots \pi$ stacking.

In summary, we have demonstrated that the incorporation of a chiral spacer between two remote boroxines can be achieved via a dipyridyl template. The 4-pyridyl and 3-pyridyl ligands in both the ester and ether series gave the respective boroxines, but the 2pyridyl ligands $\mathbf{3 c}$ and $\mathbf{4} \mathbf{c}$ failed to give the desired adducts. Formation of the bis-boroxine structures were supported by NMR and mass spectral analysis, as well as via single crystal X-ray analysis of $\mathbf{3 a . 6} \mathbf{6}_{2}$. The solid state structure of this adduct illustrates that the boroxine assemblies can enhance the chiral pocket, both in size and shape in the solid state. We are currently investigating the use of this chiral cavity, and the role of boroxines in self-assembly.

\section{Acknowledgments}

We gratefully acknowledge financial support from the Department of Chemistry at Loughborough University.

\section{References and notes}

1. (a) Stetter, H.; Reischl, A. Chem. Ber. 1960, 93, 791; (b) Tatemitsu, H.; Ogura, F.; Nakagawa,Y.; Nakagawa, M.; Naemura, K.; Nakagawa, M. Bull. Chem. Soc. Jpn. 1975, 48, 2473; (c) For a review, see: Turner, J. J.; Harding, M. M. Supramol. Chem. 2005, 17,369 .

2. (a) Tröger, J. J. Prakt. Chem. 1887, 36, 225; (b) Rúnarsson, Ö. V.; Artacho, J.; Wärnmark, K. Eur. J. Org. Chem. 2012, 7015.

3. (a) Try, A. C.; Painter, L.; Harding, M. M. Tetrahedron Lett. 1998, 39, 9809. (b) Kimber, M. C.; Try, A. C.; Painter, L.; Harding, M. M.; Turner, P. J. Org. Chem. 2000, 65, 3042. (c) Field, J. D.; Turner, P.; Harding, M. M.; Hatzikominos, T.; Kim, L. New J. Chem. 2002, 26, 720. (d) Anderberg, P. I.; Turner, J. J.; Evans, K. J.; Hutchins, L. M.; Harding, M. M. Dalton Trans. 2004, 1708. (e) Lee, C. K. Y.; Groneman, J. L.; Turner, P.; Rendina, L. M.; Harding, M. M. Tetrahedron 2006, 62, 4870.

4. (a) Naemura, K.; Fukunaga, R. Chem. Lett. 1985, 1651. (b) Naemura, K.; Fukunaga, R.; Yamanaka, M. J. Chem. Soc., Chem. Commun. 1985, 1560. (c) Naemura, K.; Fukunaga, R.; Komatsu, M.; Yamanaka, M.; Chikamatsu, H. Bull. Chem. Soc. Jpn. 1989, 62, 83. (d) Thunberg, L.; Allenmark, S.; Friberg, A.; Ek, F.; Frejd, T. Chirality 2004, 16, 614.

5. Jilka, P.; Millington, C.; Elsegood, M. R. J.; Frese, J. W. A.; Teat S.; Kimber, M. C. Tetrahedron 2010, 66, 9327.

6. For a recent perspective on boroxines, see: Korich, A. L.; Iovine, P. M. Dalton Trans. 2010, 39, 1423.

7. (a) Snyder, H.R.; Konecky, M.S.; Lennarz, W.J. J. Am. Chem Soc. 1958, 80, 3611; (b) Beckmann, J.; Dakternieks, D.; Duthie, A.; Lim, A. E. K.; Tiekink, E. R. T. J. Organomet. Chem. 2001, 633, 149; (c) Iovine, P. M.; Gyselbrecht, C. R.; Perttu, E. K.; Klick, C.; Neuwelt, A.; Loera, J.; Di Pasquale, A. G.; Rheingold, A. L.; Kua, J. Dalton Trans. 2008, 3791.

8. Cote, A. P.; Benin, A. I.; Ockwig, N. W.; O'Keeffe, M.; Matzger, A. J.; Yaghi, O. M. Science 2005, 310, 1166.

9. Representative bis-boroxine formation procedure for $3 \mathbf{3 a}_{\mathbf{6}}$. To a solution of $3 \mathbf{a}(20 \mathrm{mg}, 0.046 \mathrm{mmol})$ in $\mathrm{CH}_{2} \mathrm{Cl}_{2}(5 \mathrm{~mL})$ was added phenylboronic acid ( $34 \mathrm{mg}, 0.276 \mathrm{mmol})$ and the resultant solution was stirred for $2 \mathrm{~h}$ (rapid solublisation of $\mathrm{PhB}(\mathrm{OH})_{2}$ was noted). After this period, the solvent was removed under reduced pressure to give a white solid that was recrystallised from $\mathrm{CH}_{2} \mathrm{Cl}_{2}$ /petroleum ether to give the bis-boroxines as colourless crystals (38 mg, $78 \%) ;{ }^{1} \mathrm{H}$ NMR $\left(400 \mathrm{MHz}, \mathrm{CDCl}_{3}\right) \delta 9.01$ (d, $J$ $=6.4 \mathrm{~Hz}, 4 \mathrm{H}), 8.11-8.09(\mathrm{~m}, 12 \mathrm{H}), 7.64(\mathrm{~d}, J=6.0 \mathrm{~Hz}, 4 \mathrm{H}), 7.42$ $-7.40(\mathrm{~m}, 18 \mathrm{H}), 7.31(\mathrm{~d}, J=7.2 \mathrm{~Hz}, 2 \mathrm{H}), 7.12(\mathrm{t}, J=7.2 \mathrm{~Hz}, 2 \mathrm{H})$, $7.04(\mathrm{t}, J=7.2 \mathrm{~Hz}, 2 \mathrm{H}), 6.88(\mathrm{~d}, J=7.2 \mathrm{~Hz}, 2 \mathrm{H}), 5.28(\mathrm{~d}, 15.6 \mathrm{~Hz}$, $2 \mathrm{H}), 4.88(\mathrm{~s}, 2 \mathrm{H}), 4.88(\mathrm{~d}, J=15.6 \mathrm{~Hz}, 2 \mathrm{H}), 3.50-3.48(\mathrm{~m}, 2 \mathrm{H})$, $2.40-2.39(\mathrm{~m}, 2 \mathrm{H}) ;{ }^{13} \mathrm{C} \mathrm{NMR}\left(100 \mathrm{MHz}, \mathrm{CDCl}_{3}\right) \delta 153.7,143.6$, $137.9,136.0,134.0,133.5,131.5,130.5,130.0,128.2,127.7$, 127.6, 127.3, 127.0, 127.0, 126.5, 123.0, 81.8, 69.1, 34.9, 29.1 MS-ESI found 1081.4452, $\mathrm{C}_{65} \mathrm{H}_{56} \mathrm{~B}_{6} \mathrm{~N}_{2} \mathrm{O}_{8} \mathrm{Na}[\mathrm{M}+\mathrm{Na}]^{+}$requires 1081.4493.

10. Selected physical data:

3b.6 3 $_{2}$ as colourless crystals; ${ }^{1} \mathrm{H}$ NMR $\left(400 \mathrm{MHz}, \mathrm{CDCl}_{3}\right) \delta 9.11$ (s, $2 \mathrm{H}), 9.01(\mathrm{~d}, J=5.6 \mathrm{~Hz}, 2 \mathrm{H}), 8.09-8.07(\mathrm{~m}, 12 \mathrm{H}), 7.59(\mathrm{t}, J=$ $6.8 \mathrm{~Hz}, 2 \mathrm{H}), 7.40-7.37(\mathrm{~m}, 2 \mathrm{H}), 7.30-7.24(\mathrm{~m}, 2 \mathrm{H}), 7.04-$ $6.95(\mathrm{~m}, 6 \mathrm{H}), 5.26(\mathrm{~d}, J=12.8 \mathrm{~Hz}, 2 \mathrm{H}), 4.87(\mathrm{~d}, J=12.8 \mathrm{~Hz}, 2 \mathrm{H})$, $4.86(\mathrm{~d}, J=5.2 \mathrm{~Hz}, 2 \mathrm{H}), 3.52-3.51(\mathrm{~m}, 2 \mathrm{H}), 2.36-2.35(\mathrm{~m}, 2 \mathrm{H})$; ${ }^{13} \mathrm{C}$ NMR $\left(100 \mathrm{MHz}, \mathrm{CDCl}_{3}\right) \delta 142.9,142.3,139.7,138.2,137.0$, $136.1,134.0,133.9,133.6,131.3,130.4,130.0,128.4,128.1$, 127.7, 127.6, 127.0, 126.4, 125.6, 81.7, 68.1, 35.0, 29.1; MS-ESI found $1081.4462, \mathrm{C}_{65} \mathrm{H}_{56} \mathrm{~B}_{6} \mathrm{~N}_{2} \mathrm{O}_{6} \mathrm{Na}[\mathrm{M}+\mathrm{Na}]^{+}$requires 1081.4493 4a. $\mathbf{6}_{2}$ as colourless crystals; ${ }^{1} \mathrm{H} \mathrm{NMR}\left(400 \mathrm{MHz}, \mathrm{CDCl}_{3}\right) \delta 8.95(\mathrm{~d}$, $J=5.2 \mathrm{~Hz}, 4 \mathrm{H}), 8.14-8.12(\mathrm{~m}, 6 \mathrm{H}), 7.94(\mathrm{~d}, J=5.2 \mathrm{~Hz}, 4 \mathrm{H})$, $7.72(\mathrm{~d}, J=6.8 \mathrm{~Hz}, 4 \mathrm{H}), 7.49-7.38(\mathrm{~m}, 22 \mathrm{H}), 7.21-7.08(\mathrm{~m}$, $4 \mathrm{H}), 6.89(\mathrm{~d}, J=7 . \mathrm{Hz}, 2 \mathrm{H}), 6.57(\mathrm{~d}, J=6.0 \mathrm{~Hz}, 2 \mathrm{H}), 3.73-3.71$ $(\mathrm{m}, 2 \mathrm{H}), 2.60-2.59(\mathrm{~m} 2 \mathrm{H}) ;{ }^{13} \mathrm{C}$ NMR $\left(100 \mathrm{MHz}, \mathrm{CDCl}_{3}\right) \delta$ $164.5,148.9,134.7,134.6,133.8,133.5,131.3,131.1,128.2$, 128.0, 127.9, 127.4, 127.0, 124.0, 76.0, 35.8; MS-ESI found 1109.4062, $\mathrm{C}_{65} \mathrm{H}_{52} \mathrm{~B}_{6} \mathrm{~N}_{2} \mathrm{O}_{10} \mathrm{Na}[\mathrm{M}+\mathrm{Na}]^{+}$requires 1109.4078 . 4b.6 2 as colourless crystals; ${ }^{1} \mathrm{H}$ NMR $\left(400 \mathrm{MHz}, \mathrm{CDCl}_{3}\right) \delta 9.50$ $(\mathrm{d}, J=1.6 \mathrm{~Hz}, 2 \mathrm{H}), 9.06(\mathrm{dd}, J=1.2,5.6 \mathrm{~Hz}, 2 \mathrm{H}), 8.42(\mathrm{~d}, J=8.0$ $\mathrm{Hz}, 2 \mathrm{H}), 8.13-8.11(\mathrm{~m}, 12 \mathrm{H}), 7.73(\mathrm{~d}, J=7.2 \mathrm{~Hz}, 2 \mathrm{H}), 7.56(\mathrm{dd}$, $J=5.6,8.4 \mathrm{~Hz}, 2 \mathrm{H}), 7.49-7.40(\mathrm{~m}, 18 \mathrm{H}), 7.17-7.06(\mathrm{~m}, 4 \mathrm{H})$, $6.94(\mathrm{~d}, J=8.0 \mathrm{~Hz}, 2 \mathrm{H}), 6.61(\mathrm{~d}, J=6.0 \mathrm{~Hz}, 2 \mathrm{H}), 3.73-3.71(\mathrm{~m}$, $2 \mathrm{H}), 2.62(\mathrm{t}, J=3.2 \mathrm{~Hz}, 2 \mathrm{H}) ;{ }^{13} \mathrm{C} \mathrm{NMR}\left(100 \mathrm{MHz}, \mathrm{CDCl}_{3}\right) \delta$ $164.3,150.8,150.7,148.7,139.5,134.7,133.9,131.3,131.2$, 131.0, 127.1, 128.1, 127.9, 127.3, 127.3, 126.9, 124.7, 75.9, 36.0, 


\section{Tetrahedron}

29.1; MS-ESI found 1109.4042, $\mathrm{C}_{65} \mathrm{H}_{52} \mathrm{~B}_{6} \mathrm{~N}_{2} \mathrm{O}_{10} \mathrm{Na}[\mathrm{M}+\mathrm{Na}]^{+}$ requires 1109.4078 .

11. See the Supporting information for a comparison of the ${ }^{1} \mathrm{H}$ NMR spectra of 3a and 3a.6.

12. Crystal data for $\mathbf{3 a . 6} \cdot \mathbf{6}_{2} \cdot \mathbf{C C H}_{2} \mathbf{C l}_{2}: \mathrm{C}_{68} \mathrm{H}_{62} \mathrm{~B}_{6} \mathrm{Cl}_{6} \mathrm{~N}_{2} \mathrm{O}_{8}, M=1312.76$, monoclinic, space group $C 2 / c, a=26.488(5), b=16.113(3), c=$ 16.634(3) $\AA, \beta=110.583(2)^{\circ}, V=6646(2) \AA^{3}, T=150 \mathrm{~K}, Z=4$, $\mu(\mathrm{Mo}-\mathrm{K} \alpha)=0.315 \mathrm{~mm}^{-1}, 34672$ reflections measured using a Bruker APEX II CCD diffractometer with graphitemonochromated Mo-K $\alpha$ radiation $(\lambda=0.71073 \AA$ ). 8665 independent data, $R_{\text {int }}=0.0200$; all unique data used in refinement against $F^{2}$ values to give $w R 2=0.2025$ (on $F^{2}$ for all data), $R=$ 0.0658 \{for 7043 data with $\left.F^{2}>2 \sigma\left(F^{2}\right)\right\}$. Programs used were Bruker APEX II ${ }^{13}$, SAINT ${ }^{13}$, and SHELXL-2014. ${ }^{14,15}$

Crystallographic data (excluding structure factors) for the structure in this paper have been deposited with the Cambridge Crystallographic Data Centre as supplementary publication no. CCDC 1023502. Copies of the data can be obtained, free of charge, on application to CCDC, 12 Union Road, Cambridge CB2 1EZ, UK, (fax: +44-(0)1223-336033 or e-mail: deposit@ccdc.cam.ac.Uk)

13. APEX II and SAINT software for CCD diffractometers, Bruker AXS Inc, Madison, WI, 2008.

14. Sheldrick, G. M.. SHELXTL user manual, version 5, Bruker AXS Inc., Madison, WI, 1994.

15. Sheldrick, G.M., Acta Crystallogr. 2008, A64, 112-122.

\section{Supplementary Material}

Supplementary material including ${ }^{1} \mathrm{H}$ and ${ }^{13} \mathrm{C}$ NMR spectra of 3a.6 ${ }_{2}, 3 \mathbf{b . 6} \mathbf{6}_{2}, \mathbf{4 a . 6 _ { 2 }}$ and $\mathbf{4 b . 6 _ { 2 }}$, and the Crystallographic data for $3 \mathrm{a} .6_{2} \cdot 3 \mathrm{CH}_{2} \mathrm{Cl}_{2}$. 